\title{
Trade-off of Tree Conservation and Crop Production on Agroforestry Parklands in Burkina Faso
}

\author{
Tiga Neya (Corresponding author) \\ WASCAL Climate Change and Land Use Program, Department of Civil Engineering, Kwame \\ Nkrumah University of Sciences and Technology, Kumasi, Ghana \\ Tel: (+226) $79072888 \quad$ E-mail: neyatiga@gmail.com \\ Akwasi. A. Abunyewa \\ Department of Agroforestry, Kwame Nkrumah University of Sciences and Technology, \\ Kumasi, Ghana \\ Tel: (+233) 245930040 E-mail: aaabunyewa.agric@knust.edu.gh \\ Oblé Neya \\ Competence Centre, West African Science Service Center on Climate change and Adapted \\ Land Use (WASCAL), Ouagadougou, Burkina Faso \\ Tel: (+226) 70359115 E-mail: neya.o@wascal.org \\ Daniel Callo-Concha \\ Center for Development Research (ZEF). University of Bonn. Germany \\ Tel: (+49) 228731795 E-mail: d.callo-concha@uni-bonn.de
}

Received: Dec. 10, 2018 Accepted: Jan. 16, $2019 \quad$ Published: Jan. 26, 2019

doi:10.5296/jas.v7i1. $14270 \quad$ URL: https://doi.org/10.5296/jas.v7i1.14270

\begin{abstract}
Rapid population growth coupled with food demand make land for agriculture scarcer obliging farmers to make use of any available piece of land at their disposal for crops production. This preferential use of land for crops production may appear to be competitive with tree keeping on farm. To elucidate that, the trade-off between crop production and tree conservation on farms was assessed in Bouroum-Bourmoum, Sapouy and Ouahigouya, three municipalities of Burkina Faso. More than 3000 individual trees which spreading was 1154 in Bouroum-Bourom, 884 in Ouahigouya and 1054 in Sapouy were used. The mean tree canopy cover and tree cover in the farms were calculated. The three principal crops (millet, red sorghum and white sorghum) yield were used to estimate the trade-off using the mean tree canopy cover as the potential no cropping area. The results revealed a tree canopy cover of $66.25 \mathrm{~m}^{2}$ in Bouroum-Bourom, $59.92 \mathrm{~m}^{2}$ in Sapouy and $42.1 \mathrm{~m}^{2}$ in Ouahigouya. The average tree cover was $23.99 \%$ in Bouroum-Bouroum, $18.23 \%$ in Sapouy and $14.88 \%$ in Ouahigouya. This represents a loss in grain production of $109.5 \mathrm{~kg} / \mathrm{ha}$ in Bouroum-Bouroum, $247.6 \mathrm{~kg} / \mathrm{ha}$ in Sapouy and $252.8 \mathrm{~kg} / \mathrm{ha}$ in Ouahigouya. A higher tree cover implies a higher
\end{abstract}


trade-off in the agroforestry parkland and suggests reduction in tree density. There is urgent need to work out the balance between smallholders' farmer continuous requirement for increase food crop production and the need to maintain tree diversity in the farm for carbon credit payment promotion.

Keywords: smallholders, trade-off, tree conservation, crop production, canopy cover

\section{Introduction}

In Sahelian countries, smallholder farming is widely dominated by parkland land use system, composed of scattered trees that share the space with underwood crops and livestock (Bationo et al., 2012). Parkland management system is based on socio-ecological knowledge of farmers in dealing with the variability of climate, to cope with climate change and to overcome the adversity of soil fertility loss and land degradation (Arbonier, 2002; Adjatin, 2006; IAASTD, 2009). In Burkina Faso, economy is essentially based on natural resources, and agriculture which keeps busy more than $80 \%$ of the population (INSD, 2006). Agroforestry parkland is the most widely spread farming system throughout the countryside. However, beside climate variability, soil degradation continues to be the most important factor limiting crop production (Soubeiga, 2004; FAO and WWF, 2008) and tree density within farm land will reduce every year (Bayala et al., 2014).

Several studies have shown the importance of agroforestry parkland trees for food security (FAO, 2011; Bationo et al., 2012; Neufeldt et al., 2012) and sustainable soil management (Bationo and Buerkert, 2001; Bayala et al., 2008). It has been demonstrated that crop under trees were less exposed to excessive temperature, wind speed, water stress and to daily temperature variation during drought spell than in open area (Brenner, 1996; Jonsson et al., 1999; Schroth et al., 2000; Bayala et al., 2013). These stress adaptation indicators are good signs of crop productivity improvement and system resilience to climate variability. Hansson (2006) and Sanou (2010) reported higher soil porosity under tree compared to adjacent open area in the Sahel zones where water scarcity is the most limiting factor of productivity. Moreover, soil under trees has shown higher water infiltration and increased soil nutrient exchange capacity, which is a good sign for improved crop production. According to Sanou (2010), modification of soil properties and microclimate in agroforestry parklands can be due to the morphological characteristics of tree species in term of height, density, crown and shape.

Though there is positive impact of trees on crop productivity, it has been widely reported that trees and crops compete for above-ground growth resources such as light, heat, air relative humidity, and rain interception (Parkouda et al., 2007, Sanou et al., 2012). Below-ground, the competition is for water and nutrients, although it is generally expected that the roots of trees and crops occupy different soil layers, at least to some extent (Van Noordwijk and Ong, 1999; Cannell et al., 1999).

Based on the above, it appears that there are different schools of thought regarding the impacts of trees in farm lands. While one group of researchers appreciate and encourage parklands promotion, a second put much more emphasis on the negative effects of parkland trees in smallholders farming system. Therefore, there is a need to get a better insight into these apparent contradictory positions. The few studies carried out on trade-off between trees 


\section{Macrothink}

keeping and crop production were mainly in research stations and covered limited agroforestry species (Rodríguez et al., 2006; Bationo et al., 2012). Moreover, most of these studies failed to quantify the trade-off between crop production and the benefits gained from tree keeping (Balmford et al., 2002; MEA, 2005; Rodríguez et al., 2006).

In the current study an attempt has been made to estimate crop production under tree canopy in case of no-presence of trees in farms. This production was assimilated to the trade-off of tree conservation on farm, the assumption being that tree presence humpers crop production under their canopy. More specifically, the trade-off between parkland trees conservation and crop production was investigated, trough (i) tree canopy cover assessment within farms, (ii) evaluation of trees cover in farms and (iii) estimation of trade-off between crop production and tree conservation.

The results represented in this paper are synthesis of data collected across three climatic zones in Burkina Faso.

\section{Material and Method}

\subsection{Study Sites}

The study was carried out in Bouroum-Bouroum $\left(10^{\circ} 32^{\prime} \mathrm{N}, 3^{\circ} 14^{\prime} \mathrm{W}\right)$, Sapouy $\left(11^{\circ} 33^{\prime} \mathrm{N}, 1^{\circ}\right.$ $\left.46^{\prime} \mathrm{W}\right)$ and Ouahigouya $\left(13^{\circ} 35^{\prime} 00^{\prime \prime} \mathrm{N}, 2^{\circ} 25^{\prime} 00^{\prime \prime} \mathrm{W}\right)$, municipalities located in three different climatic zones of Burkina Faso (Figure 1).

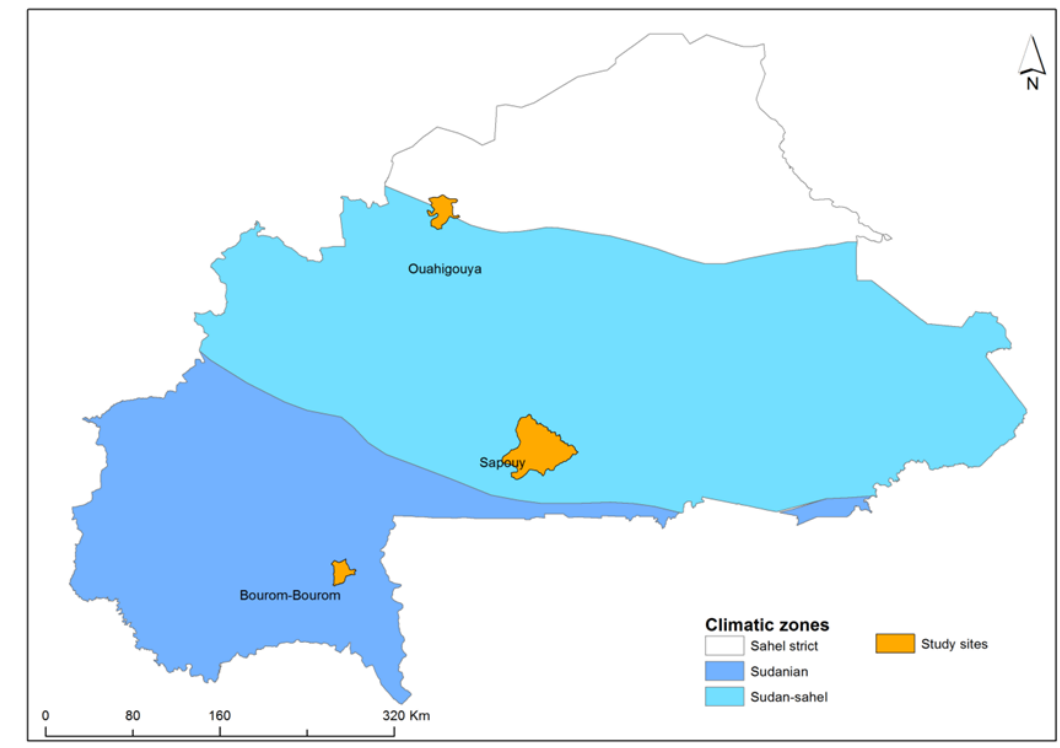

Figure 1. Location of the three study sites namely Ouahigouya (Sahel strict), Sapouy (Sudan -Sahel) and Bouroum-Bouroum (Sudanian)

Regarding climate characteristics, the average annual temperature in Bouroum-Bouroum is $27.7^{\circ} \mathrm{C}$ and the amount of annual precipitation is estimated to be $1000 \mathrm{~mm}$ (Figure 2a). Sapouy climate is characterised by an average annual rainfall of $884 \mathrm{~mm}$ and $27.6^{\circ} \mathrm{C}$ as average temperature (Figure 2b). Finally, for Ouahigouya, located in the dryer climatic zone, the annual amount of precipitation average is $599 \mathrm{~mm}$ with an average annual temperature of $28.7^{\circ} \mathrm{C}$ (Figure 2c). 

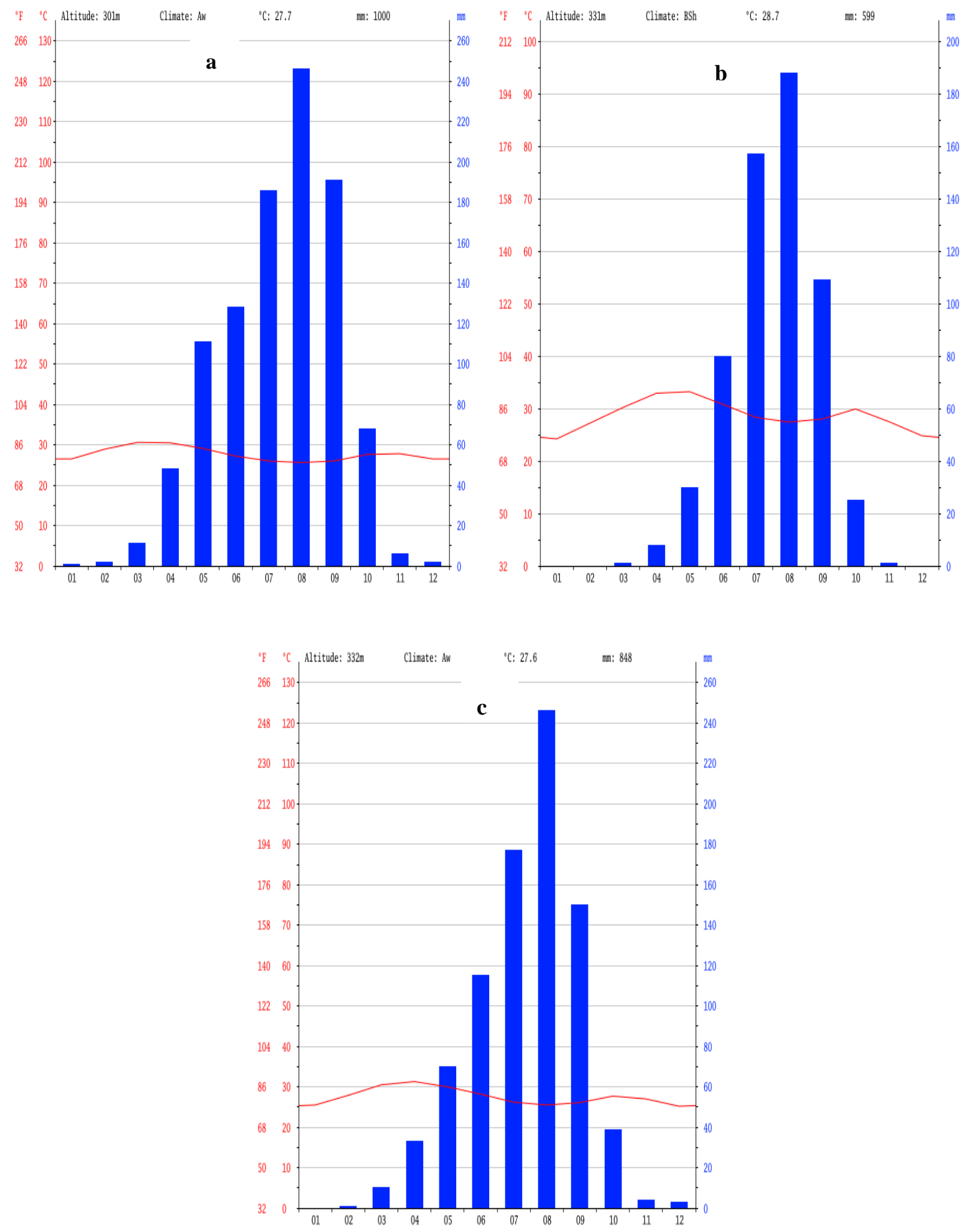

Figure 2. Average temperature and precipitation trend in Bouroum_Bouroum (2a), Sapouy (2b) and Ouahigouya (2c)

Source's: https://en.climate-data.org

The three municipalities were chosen based on farmers' experience gained through the National Forestry Investment Programme (FIP) and the Ecosystem Based Adaptation project 


\section{Macrothink

(EBA) and their ability to work with partners. In each of the three municipalities, 30 households were randomly selected among farmers that had participated in similar activities with FIP or EBA and the total area covered was about 35 ha per municipality.

\subsection{Tree Canopy Cover}

Canopy cover is defined in this study as the vertical projection of a tree's outmost perimeter and constitutes the potential shaded area which can influence crop production (Jennings, et al., 1999). To estimate canopy area all trees were inventoried and the big radius of canopy cover $\left(R_{b}\right)$ and the small radius of canopy cover $\left(R_{s}\right)$ were recorded. The formula of ellipse (Equation 1) was applied to obtain the area of canopy $\left(\mathrm{C}_{\mathrm{a}}\right)$.

$$
C_{a}=\pi \times R_{b} \times R_{s}
$$

Total canopy area under trees $\left(\mathrm{TC}_{\mathrm{a}}\right)$ of each farm was obtained by summing up the canopy cover areas of all trees within the farm (Equation 2).

$$
\mathrm{TC} a=\sum_{i=1}^{n} C a_{i}
$$

The total farm size for each municipality $(\mathrm{Tb})$ was computed as indicated in Equation 3.

$$
T b=\sum_{i=1}^{n} b i
$$

Where bi: area of each farm

The average tree canopy cover is the sum of canopy cover in $\mathrm{m}^{2}$ of the agroforestry parkland divided by the total number of trees in the parkland (Equation 4).

$$
m=\frac{T C a}{N}
$$

With m: average canopy cover

TCa: total canopy cover of agroforestry parkland

$\mathrm{N}$ : total number of trees in the agroforestry parkland

\subsection{Tree Cover}

Tree cover is the ratio (r) of tree canopy area over the total size of the farm. It is used for the estimation of vegetation cover of the site. It was computed using (Equation 5).

$$
r=100\left(\frac{\sum_{i=1}^{n} C a_{i}}{\sum_{i=1}^{n} b_{i}}\right)
$$

\subsection{Estimation of Crop Yield}

For crop yield, a database of the last eleven years from the ministry of agriculture of common crops such as red sorghum, white sorghum and millet was used. The average yield of 


\section{Macrothink}

common crop (Y) was obtained using (Equation 6)

$$
Y=\frac{\sum_{i=1}^{n} y_{i}}{N}
$$

Y: average yield of a given crop

$\mathrm{y}_{\mathrm{i}:}$ annual crop yield of common crop i

$\mathrm{N}$ : number of years

\subsection{Trade-offs Between Tree Coverage and Crop Production}

Trade-off ( $\mathrm{T}$ ) in this study is defined as the crop production that a farmer would have harvested on the farm land occupied by trees (TCa). It was obtained by multiplying crop yield (Y) by tree cover in the farm (Equation 7). The measurement was applied on 1154 trees in Bouroum-Bourom, 884 trees in Ouahigouya and 1054 trees in Sapouy.

$$
T=Y \sum_{i=1}^{n}(a)_{i}
$$

\subsection{Data Analysis}

Statistical analyses were done with Minitab 17, Excel and Sigma plot 13.0 software. One-way Fisher Pairwise Comparisons and Tukey Pairwise Comparisons tests using One-way Anova were used to see how tree canopy cover, tree cover, trade-off differ between the three climatic zones. For the all tests the significance level was set at $5 \%$.

\section{Results and Discussion}

\subsection{Tree Canopy Cover}

The results revealed a mean tree canopy cover of $66.25 \mathrm{~m}^{2}, 59.92 \mathrm{~m}^{2}$ and $42.1 \mathrm{~m}^{2}$ in Bouroum-Bourom, Sapouy and Ouahigouya municipalities, respectively. These means tree canopy cover was significantly different $(\mathrm{p}=0.001)$ from one site to another (Figure 3 ).

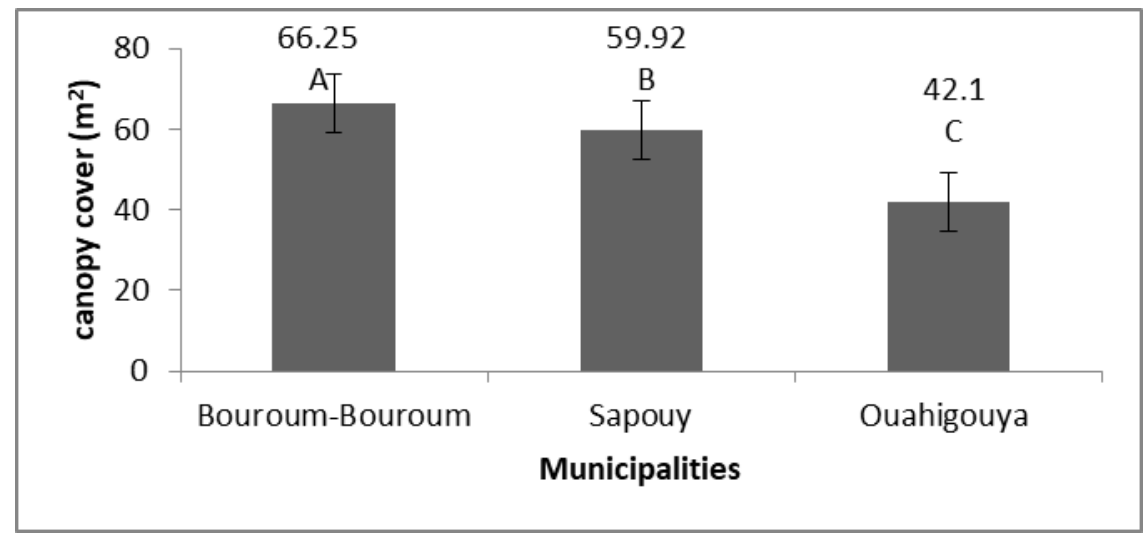

Figure 3. Mean tree canopy cover in the study sites located in three different climatic zones in Burkina Faso, A= Bouroum-Bouroum (Sudanian zone), B = Sapouy (Sudan-Sahel zone) and

$$
\mathrm{C}=\text { Ouahigouya (Sahel strict zone) }
$$




\section{Macrothink Institute ${ }^{T M}$}

The differences observed between mean tree canopy cover in the three sites can be explained by difference in dominant tree species in the three zones. Indeed, individual tree canopy varies significantly from a species to another one (Table1). Also, on farm management practices such as tree pruning (Picture 1) can influence a lot tree canopy.

Table 1. Average tree canopy cover (TCC) of trees in the three study sites, located in three climatic zones of Burkina Faso

\begin{tabular}{llll}
\hline Municipalities & Tree species & Average canopy cover $\left(\mathbf{m}^{2}\right)$ & $\begin{array}{c}\text { IVI } \\
(\%)\end{array}$ \\
\cline { 2 - 4 } & Lannea microcarpum & $63.71+12.5^{\mathrm{a}}$ & 19 \\
& Sclerocarya birrea & $53.86+11.18^{\mathrm{a}}$ & 15 \\
Ouahigouya & Azadiratha indica & $48.49+11.18^{\mathrm{ab}}$ & 13 \\
& Balanites aegyptyaca & $25.99+11.19 \mathrm{~b}^{\mathrm{c}}$ & 11 \\
& Adensonia digitata & $8.99+11.18^{\mathrm{c}}$ & 8 \\
& Feiderbia albida & $47.81+11.18^{\mathrm{ab}}$ & 7 \\
Sapouy & Vitellaria paradoxa & $60.57+23.45^{\mathrm{ab}}$ & 61 \\
& Parkia biglobosa & $96+23.5^{\mathrm{a}}$ & 6 \\
\hline Bouroum-Bouroum & Bombax constatum & $48.7+26.21^{\mathrm{b}}$ & 4 \\
\hline & Vitellaria paradoxa & $55.51+4.54$ & 78 \\
\hline
\end{tabular}

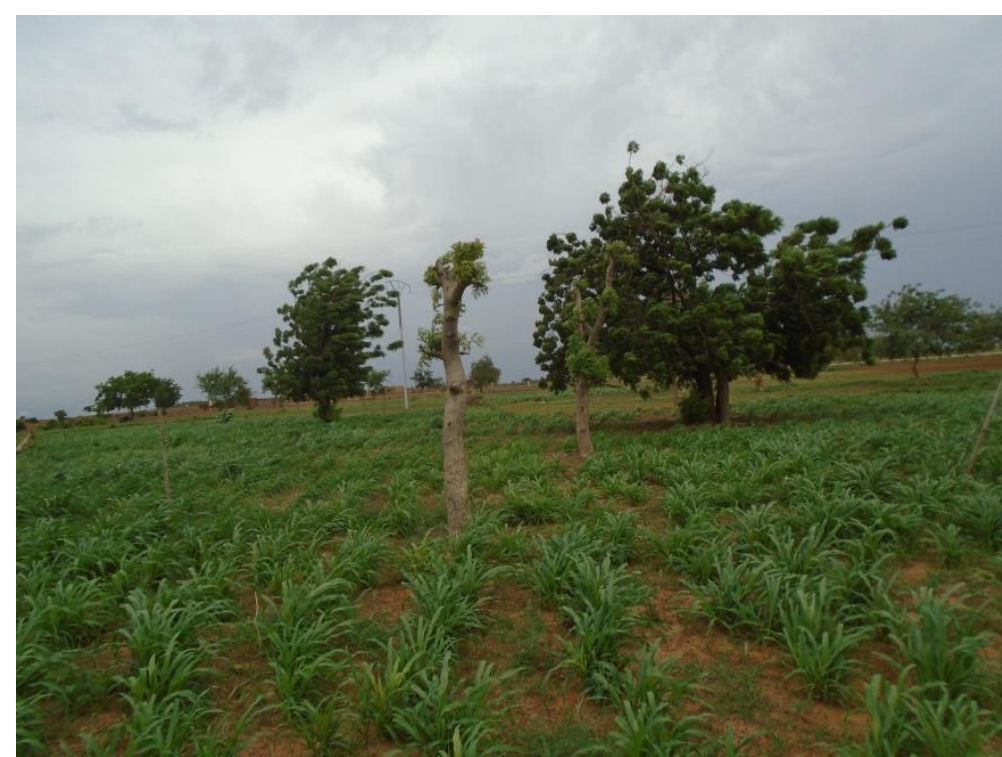

Picture 1. Trees pruning affecting tree canopy in Ouahigouya agroforestry parklands

Among the six major species found in the agroforestry parkland in Ouahigouya municipality, statistical analysis revealed significant differences in canopy cover $(\mathrm{p}$-value $=0.001)$ with high value at $63 \pm 12.5$ for Lannea microcarpum and low value at $8.99 \pm 11.8$ for Adansonia digitata. The lower canopy cover of Adansonia digitata observed in this area can be explained by the fact that it leaves are usually harvested by farmers for stew/sauce 
preparation. However, the fruit of Lannea microcarpum is the most sought as ecosystem service by farmers. Therefore, a big canopy cover of this species augurs a promising fructification capacity. The type of ecosystem service provided by each tree species guide it canopy cover management by farmers.

The results of this study are similar to the findings of Nelson et al., (2009) who reported that, the morphological characteristic of agroforestry tree species determined their canopy cover shape. Moreover, the morphological characteristic of the species and the management practices developed by the farmers also contributed to shape the canopy cover (Bationo et al., 2012; Bayala et al., 2014). According to Bationo et al., (2012), farming system should play various role to cover farmers' needs in term of wood and non-timber products where the forests resources are scarce. And regarding forest resources availability, it has been argued that in Burkina Faso, forest resources decreased from the southern to the northern region of the country (DIFOR, 2007).

\subsection{Tree Cover}

Tree cover in Bouroum-Bouroum and Ouahigouya municipalities were significantly different while no significant difference was observed between tree cover in Sapouy and any other site. However, this parameter seems to decrease along a climatic gradient going from Bouroum-Bouroum (Sudanian) to Ouahigouya (Sahel strict) municipality (Figure 4).

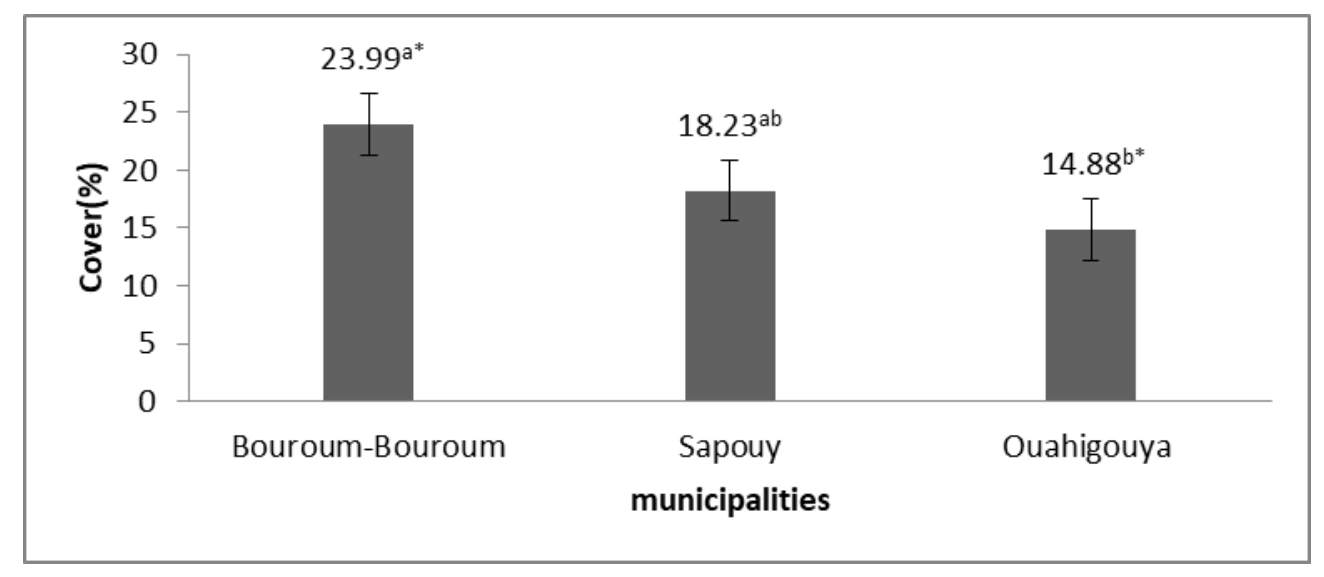

Figure 4. Tree cover in the study sites located in three different climatic zones in Burkina Faso, Bouroum-Bouroum (Sudanian zone), Sapouy (Sudan-Sahel zone) and Ouahigouya (Sahel strict zone)

(* significance at $\mathrm{p}=0.001)$

The highest tree cover value of $23.99 \% \pm 3.61$ was observed in Bouroum-Bouroum and the lowest value of $14.88 \% \pm 3.61$ in Ouahigouya municipality. These results can be explained by the difference observed between the canopy cover of tree species (Table 1). United Nations Food and Agriculture Organization (FAO, 2015) has defined forest as land with a tree canopy cover higher than $10 \%$ in an area larger than 0.5 ha. Based on this definition, all agroforestry parklands investigated in this study may be considered as forests. This corroborates the findings reported by Zoungrana et al. (2015), who argued that high density of trees in farmlands in Dano (Sudanian zone) did not allow a good distinction between a forest and a 
farmland using Landsat images. Yet, the high tree cover values of this study contradict the findings of Gijsbers et al. (2003), who estimated tree cover in West Africa parkland systems at $10 \%$.

The relative high tree cover value observed in all the study sites can be interpreted as the effects of sensitization at national level on the importance and the roles that trees can play on farms regarding building farmers resilience. One would have expected tree cover to be significantly different from the Sahel strict zone (Ouahigouya) to the Sudan-Sahel zone (Sapouy). This lack of significance in difference may be explained by farming practices (Picture 2A, 2B and 2C) adopted by some farmers in the second zone to reduce tree density within the farms as prerequisite for more mechanisation in this area.

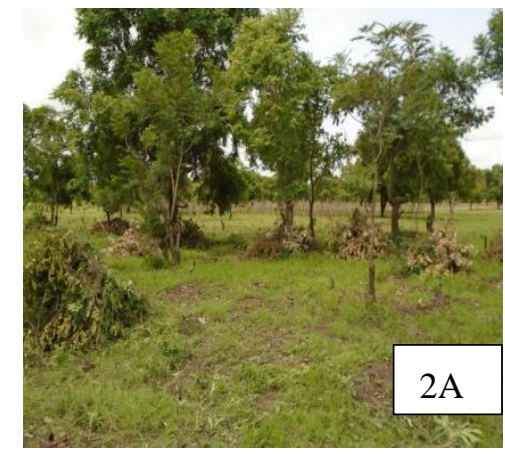

Fire method to destroy tree new farm

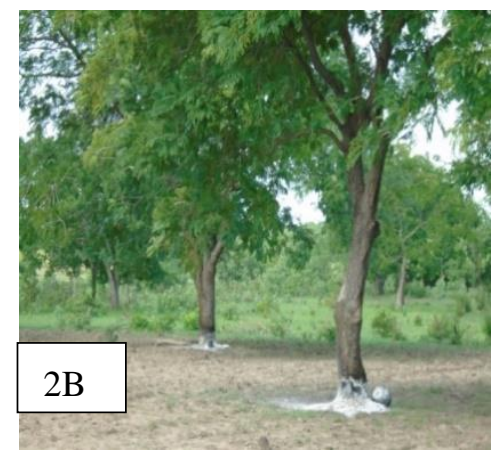

Fire mothod to destroy tree old farm

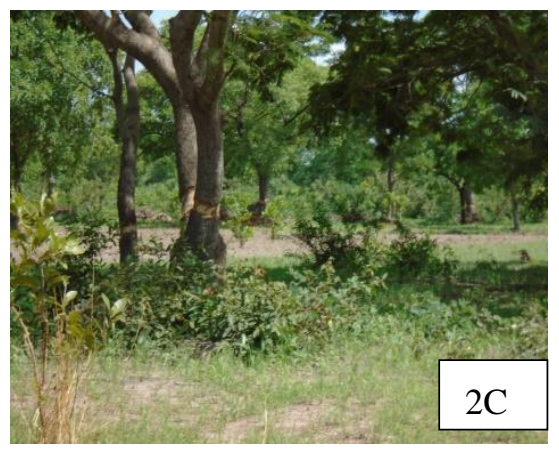

Cernage method to destroy tree in the farm

Picture 2. Methods used by some farmers to eliminate trees in agroforestry parklands in Sudan-Sahel and Sudanian zones of Burkina Faso

\subsection{Crop Yields}

The mean yield of crops used for this study purpose are given by Table 2 .

Table 2. Mean yield of the three crops commonly planted in the study sites located in three different climatic zones in Burkina Faso, Bouroum-Bouroum (Sudanian zone), Sapouy (Sudan-Sahel zone) and Ouahigouya (Sahel strict zone)

\begin{tabular}{cccc}
\hline Municipalities & Crop types & Cield(kg) & \\
\hline \multirow{4}{*}{ Bouroum-Bouroum (95\%) } & White sorghum & 1169 & $(965,1373)$ \\
& Red sorghum & 962.4 & $(777,1147.8)$ \\
& Millet & 840 & $(652,1027)$ \\
Ouahigouya & White sorghum & 842.4 & $(638.7,1046.0)$ \\
& Red sorghum & - & - \\
& Millet & 922.1 & $(734.2,1109.9)$ \\
Sapouy & White sorghum & 1205.3 & $(1001.7,1409.0)$ \\
& Red sorghum & 1317 & $(1132,1502)$ \\
& Millet & 1009.5 & $(821.7,1197.4)$ \\
\hline
\end{tabular}


Source: Ministry of Agriculture (2017), Burkina Faso

\subsection{Trade-off}

Figure 5 shows the trade-off by hectare calculated based on mean yield of each crop (millet, white sorghum and red sorghum) and tree canopy cover in the three climatic zones.

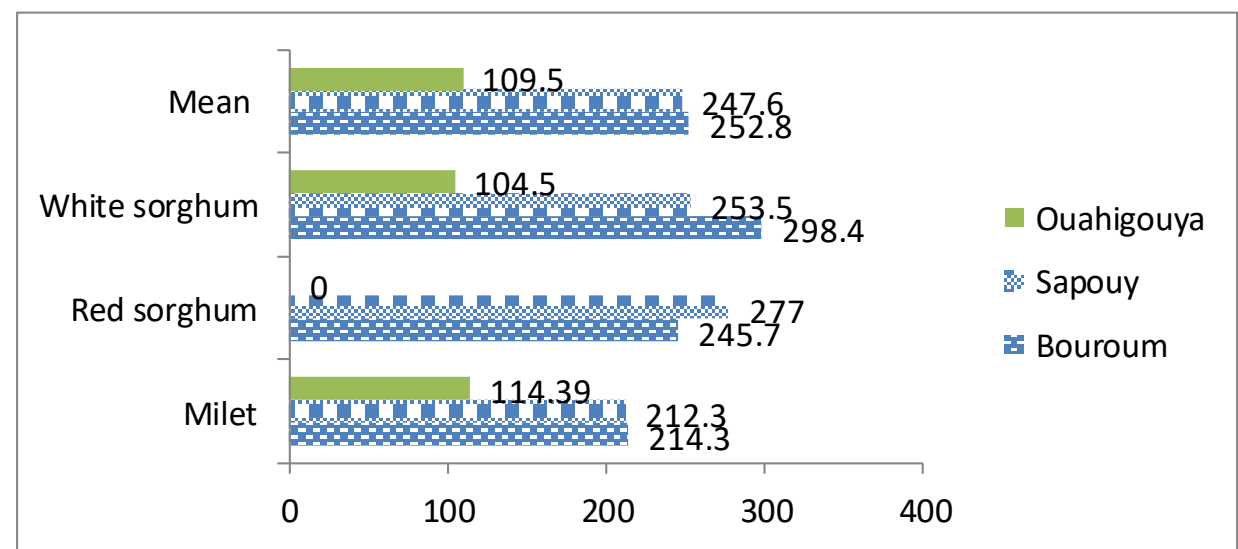

Figure 5. Trade-off per hectare $(\mathrm{kg} / \mathrm{ha})$ for three major crops and their global mean trade-off in the study sites located in three different climatic zones in Burkina Faso,

Bouroum-Bouroum (Sudanian zone), Sapouy (Sudan-Sahel zone) and Ouahigouya (Sahel strict zone)

For the three major crops considered in the study, trade-off analysis showed that the impact of tree canopy cover on crop production is less for millet compared to the two other crops (red sorghum and white sorghum) and statistical analysis revealed a significance difference between millet and sorghum trade-off at $\mathrm{p}$-value $=0.001$. The higher trade-off recorded with sorghum can be attributed to the difference between millet and sorghum yields as the mean yield of crop showed a lower yield of millet compared to sorghum varieties (Table 2). Considering study sites, the lowest global mean trade-off $(109.5 \pm 12 \mathrm{~kg} / \mathrm{ha})$ was observed in Ouahigouya while the highest $(252.8 \pm 12 \mathrm{~kg} / \mathrm{ha}$ ) was observed in Bouroum-Bouroum. Turkey test showed significant trade-off in Ouahigouya compared to Sapouy and Bouroum-Bouroum ( $\mathrm{p}$-value $=0.001)$. The lower trade-off in Ouahigouya (Sahel strict climatic zone) can be explained by the low soil fertility and the low rainfall (Figure 2).

The trade-off analysis showed $109 \mathrm{~kg} / \mathrm{ha}, 247 \mathrm{~kg} / \mathrm{ha}$ and $252 \mathrm{~kg} / \mathrm{ha}$, respectively for the study sites of Ouahigouya (Sahel strict zone), Sapouy (Sudan-Sahel zone) and Bouroum-Bouroum (Sudanian zone). These quantities of crops represent respectively 0.6, 1.36 and 1.4, of mean yearly cereal need per person in Burkina Faso (MAAH, 2017). These proportions highlight the importance of this trade-off analysis for food security issues as the trade-off per hectare in Ouahigouya, Sapouy and Bouroum-Bouroum represent respectively 60, 136 and 140\% of the yearly cereal need of one Burkinabe.

Burkina Faso plans to promote agroforestry parklands as key actions in the implementation of its National Determined Contribution in the framework of the UNFCCC Paris Agreement (MEEVCC, 2015). This would mean that some compensations must be set up to cover the trade-off induce by tree conservation in agroforestry parklands. Whenever a tree is cut to increase farming area, ecosystem service such as support to crop production is preferred to other services like provision of non-timber forest products and carbon sequestration that 
could have been rendered by the tree. Each tree cut, reduces agroforestry parkland capability to sequester atmospheric $\mathrm{CO}_{2}$ while burning of the wood of cut tree increases the atmospheric $\mathrm{CO}_{2}$. Some scientists had argued that less trade-off in favour of tree conservation could be considered as enough reason of cutting trees (Carpenter et al., 2006, Cork et al., 2006, Rodríguez et al., 2006). However, according to Waggoner (1996), whatever is the difference in terms of crop production, effect of trees on crop production should not be considered as the trade-off. For these authors scattered trees contribute to secure human security through ensuring biodiversity portfolio and saving smallholder money through multiple free ecosystem services provided in terms of climate regulation, soil water and fertility improvement, timber and no timber products provision. It has been argued that, in developed countries, more importance is given to services provided by ecosystems, making their conservation for human wellbeing easier. On the other hand, in developing countries, the conservation of some intangible ecosystem services is not considered as a priority. For instance, alleviation of poverty is usually considered as more important than environmental problems that would be incurred as consequence of tree cutting (Gray and Clara, 2005; Rodríguez et al., 2006).

\section{Conclusions}

The investigation has revealed that tree canopy cover (TCC) is a function of tree species and Parkia biglobosa has the highest TCC $(96 \pm 23.5)$ in the study area. Based on the study data, average TCC decreased from high rainfall area (Sudanian) to low rainfall area (Sahel). The average tree cover (TC) in whole study area was high (14\%) and therefore could be classified as forest in the Sahelian zone (FAO, 2015). However, this increase of TC in the farm level significantly affects crop production and subsequently the trade-off. Millet crop was less affected by increasing TCC compared to sorghum species. Tree conservation of farm may have some implications for food security as the trade-off in terms of crop production was found to be important in all the three climatic zones covered by the study. To encourage conservation of trees in the agroforestry parklands, it is highly recommended that in addition to other ecosystem services, carbon stock of agroforestry trees be assessed to determine the benefit that could be gained by smallholders' farmers in carbon payment using REED+ initiative.

\section{Acknowledgements}

Authors thank the German Federal Ministry of Education and Research (BMBF) for its financial support to this research through the West African Science Service Centre on Climate Change and Land Use (WASCAL). The authors also wish to thank smallholders' farmers and technicians whose commitments were crucial to achieving the outputs of this study.

\section{References}

Adjatin, A. (2006). Contribution à l'étude de la diversité des légumes feuilles traditionnels consommés dans le département de l'Atacora au Togo. Memoire de diplome d' études aprofondies. Université de Lomé Togo. 50p

Arbonnier, M. (2002). Arbres, arbustes et lianes de zones sèches d'Afrique de l'Ouest. CIRAD. MNHN. IUCN 573p.

Balmford, A., Bruner, A., \& Cooper, P. (2002.) Economic reasons for conserving wild nature. 
Science, 297, 950-953.

Bationo, A., \& Buerkert, A. (2001). Soil organic carbon management for sustainable land use in Sudano-Sahelian West Africa. Nutr Cycl Agroecosys, 61, 131-142.

Bationo, B. A., Kalinganire, A., \& Bayala, J. (2012). Potentialités des ligneux dans la pratique de l'agriculture de conservation dans les zones arides et semiarides de l'Afrique de l'Ouest: Aperçu de quelques systèmes candidats. ICRAF Technical Manual no. 17 Nairobi: World Agroforestry Centre.

Bayala, J., Kindt, R., Belem, M., \& Kalinganire, A. (2011). Factors affecting the dynamics of Tree diversity in agroforestry Parklands for cereal and cotton farming system in Burkina Faso. New Forest, 41, 280-296

Bayala, J., \& Ouedraogo, S. J. (2008). Agroforestry and soil fertility maintenance. In Synthesis of Soil, Water and Nutrient Management Research in the Volta Basin. Edited by Bationo A, Tabo R, Waswa BS, Okeyo J, Fosu M, Kabore S. Ecomedia Ltd.; 41-46.

Bayala, J., Sanou, J., Bazie,' P., \& van Noordwijk, M. (2013). Empirical data collection of tree effects on temperature and humidity at crop level. CRP 7 Activity Report. Nairobi: World Agroforestry Centre.

Bayala, J., Sanou, J., Teklehaimanot, Z., Kalinganire, A., \& Ouedraogo, J. S. (2014). Parklands for buffering climate risk and sustaining agricultural production in the Sahel of West Africa, Current Opinion in Environmental Sustainability, 6, 28-34. https://doi.org/10.1016/j.cosust.2013.10.004

Brenner, A. J. (1996). Microclimatic modifications in agroforestry. In Tree-Crop Interactions: A Physiological Approach,. Edited by Ong CK, Huxley P. UK: CAB International; 1996:159-187. 26.

Cannell, M. G. R., van Noordwijk, M., \& Ong, C. K. (1999). The central hypothesis: the tree must acquire resources that the crop would not otherwise acquire. Agrofor Syst, 6, 27-30.

Carpenter, S. R., Bennett, E. M., \& Peterson, G. D. (2006). Scenarios for ecosystem services: an overview. Ecology and Society, 11(1), 29.

Cork, S. J., Peterson, G. D., Bennett, E. M., Petschel-Held, G., \& Zurek, M. (2006). Synthesis of the storylines. Ecology and Society, 11(2).

http://www.ecologyandsociety.org/vol11/iss2/art11/

DIFOR (Direction des Forets). (2007). Situation des forets classées du Burkina Faso et plan de réhabilitation. $46 \mathrm{p}$.

FAO (United Nations Food and Agriculture Organization). (2011). Disaster Risk Management Strategy in West Africa and the Sahel FAO (2011-2013). Rome, Italy: FAO.

FAO. (2015). Global Forest Resources Assessment. www.fao.org/3/a-i4808e.

FAO \& WWF. (2008). Cercle de concertation des partenaires du MINFOF, thématique sur les produits forestiers non ligneux (PFNL) au Cameroun. Rapport final, 26p.

Gijsbers, H. J. M., Kessler, J. J., \& Knevel, M. K. (2003). Dynamics and natural regeneration of woody species in farmed parklands in the sahel region (Province of Passore, Burkina Faso). Forestry ecology and management, 65, 1-12. 
Gray, L. C., \& Clara, S. (2005). What kind of intensification Agricultural practice, soil fertility and socioeconomic differentiation in rural Burkina Faso, Geographical Journal, 171(1), 70-82. https://doi.org/10.1111/j.1475-4959.2005.00150.x

Hansson, L. (2006). Comparisons of Infiltration Capacities in Different Parklands and Farming Systems of Semi-arid Burkina Faso. Sweden: Swedish University of Agricultural Sciences, Department of Forest Ecology; MSc thesis.

Hunziker, M. (1995). The spontaneous reafforestation in abandoned agricultural lands - perception and aesthetic assessment by locals and tourists. Landscape and Urban Planning, 31, 399-410.

IAASTD (International Assessment of Agricultural Knowledge, Science and Technology for Development). (2009). Agriculture at a Crossroads.In: International Assessment of Agricultural Knowledge,Science and Technology for Development Global Report, Island Press, Washington, D.C.

INSD (Institut National des Statistiques et de la Démographie) .(2006). Recensement général de la population et de l'habitation. Rapport de recensement. 176p.

Jennings, S. B., Brown, N. D., \& Sheil, D. (1999). Assessing forest canopies and understorey illumination : canopy closure , canopy cover and other measures. Forestry, 72(1), 59-73.

Jonsson, K., Ong, C. K., \& Odongos, J. C. (1999). Influence of scattered néré and karité on microclimate, soil fertility and millet yield in Burkina Faso. Exp Agric, 35, 39-53.

MAAH (Ministere de l'Agriculture et des Amenagement Hydraulique), Burkina Faso. (2017). Programme d'activites 2018 et perspectives 2019-2020. 71p.

MEA (Millennium Ecosystem Assessment). (2005). Ecosystems and Human Well-Being Synthesis. Washington, DC: World Resources Institute.

MEEVCC (Ministere de l'Environnement de l'Economie Verte et du Changement Climatique. (2015) Intended Nationaly Determined Contribution (INDC) Burkina Faso. 51p.

Nelson, E., Polasky, S., \& Lewis, D. (2008). Efficiency of incentives to jointly increase carbon sequestration and species conservation on a landscape. P Natl Acad Sci USA, 105, 9471-9476.

Neufeldt, H., Dawson, I. K., Luedeling, E., Ajayi, O. C., Beedy, T., Gebrekirstos, A., ... \& Weber, J. C. (Eds). (2012). Climate change vulnerability of agroforestry. ICRAF Working Paper No. 143. Nairobi: World Agroforestry Centre.

Parkouda, C., Diawara, B., Ganou, L., \& Lamien, N. (2007). Potentialités nutritionnelles des produits de 16 especes fruitieres locales. Sci Techn Sci Appl Technol, 1, 35-47.

Rodríguez, J. P., Beard, T. D., Bennett, Jr. E. M., Cumming, G. S., Cork, S., Agard, J., ... Peterson, G. D. (2006). Trade-offs across space, time, and ecosystem services. Ecology and Society, 11(1), 28. http://www.ecologyandsociety.org/vol11/iss1/art28/

Schroth, G., Krauss,U., Gasparotto, L., Duarte-Aguilar, J. A, \& Vohland, K. (2000). Pests and diseases in agroforestry systems of the humid tropics. Agrofor Syst, 50,199-241.

Sanou, J. (2010). Optimizing Productivity of Agroforestry Parkland Systems in West Africa Using Shade Tolerant Annual Crops. Bangor, UK: University of Wales. 


\section{Macrothink}

Sanou, J., Bayala, J., Teklehaimanot, Z., \& Bazie, P. (2012). Effect of shading by baobab (Adansonia digitata) and néré (Parkia biglobosa) on yields of millet (Pennisetum glaucum) and taro (Colocasia esculenta) in parkland systems in Burkina Faso, West Africa. Agrofor Syst, 85, 431-441.

Soubeiga, K. J. (2004). Analyse de la demande des produits forestiers non ligneux dans l'alimentation des ménages ruraux : cas des départements de Bondokuy (Mouhoun) et de Niandialia (Boulkiemdé). Mémoire d'Ingénieur en Sociologie et Economie Rurales. Université Polytechnique de Bobo-Dioulasso, Burkina Faso, 57p.

Van Noordwijk, M., \& Ong, C. K. (1999). Can the ecosystem mimic hypotheses be applied to farms in African savannahs? Agrofor Syst, 45, 131-158.

Waggoner, P. E. (1996). How Much Land Can Ten Billion People Spare for Nature?, Daedalus, 125(3), 73-93.

Zoungrana, B. J., Conrad, C., Amekudzi, L. K., Thiel, M., \& Da, E. D. (2015). Land Use/Cover Response to Rainfall Variability: A Comparing Analysis between NDVI and EVI in the Southwest of Burkina Faso. Climate, 3(1), 63-77. https://doi.org/10.3390/cli3010063

\section{Copyright Disclaimer}

Copyright for this article is retained by the author(s), with first publication rights granted to the journal.

This is an open-access article distributed under the terms and conditions of the Creative Commons Attribution license (http://creativecommons.org/licenses/by/4.0/). 